\title{
Anthrovision
}

Vaneasa Online Journal

\section{Co-photographing in North-western Tigray, Ethiopia}

\section{Thera Mjaaland}

\section{(2) OpenEdition \\ Journals}

\section{Electronic version}

URL: http://journals.openedition.org/anthrovision/2617

DOI: 10.4000/anthrovision.2617

ISSN: 2198-6754

\section{Publisher}

VANEASA - Visual Anthropology Network of European Association of Social Anthropologists

\section{Electronic reference}

Thera Mjaaland, «Co-photographing in North-western Tigray, Ethiopia », Anthrovision [Online], 5.2 | 2017, Online since 31 December 2017, connection on 20 April 2019. URL : http:// journals.openedition.org/anthrovision/2617; DOI : 10.4000/anthrovision.2617

This text was automatically generated on 20 April 2019.

(C) Anthrovision 


\title{
Co-photographing in North-western Tigray, Ethiopia
}

\author{
Thera Mjaaland
}

\section{Introduction}

1 Post-colonial critiques of the unequal power relations historically informing crosscultural relationships since the 1980 s have sparked a turn to collaborative or participatory research methods. In their book, Participation: the new tyranny?, Uma Kothari and Bill Cooke (2001) address this trend in development projects which are criticised for glossing over rather than removing the inequality at play in collaborative projects. So, what exactly makes an anthropological project collaborative in an ethical sense beyond the collaboration implicit in any ethnographic endeavour when requiring rapport and ongoing dialogue over time with the people involved on the interpretation and validation of our observations? Luke Eric Lassiter (2004), who not only attempts to move the implicit ethnographic collaboration to the fore but to develop it as a basic ethical component of critical ethnography, renames his informants "consultants" or "cointellectuals". He asserts that six non- mutually exclusive strategies are commonly used when including communities as follows:: "(1) principle consultants as readers and editors, (2) focus groups, (3) editorial boards, (4) collaborative ethnographers/consultant teams (5) community forums, and (6) co-produced and co-written texts" (Lassiter 2005: 94). Based on my fieldwork experience as a photographic artist and photographing anthropologist in north-western Tigray, North-Ethiopia, this article is however not cowritten with consultants or co-intellectuals. Its argument is, nevertheless, based on coproduction of photographic images, or "co-photographing", and the discussions of these photographs with people afterwards. Through the examples of co-photographing presented below I will elaborate on the insights that gradually evolved from this visual collaboration. 
Fig. 1. The priest Mihirey Zewraweru, Mammay (with the radio) and Abraha (with the Kalashnikov). Alogen, Tigray 1997
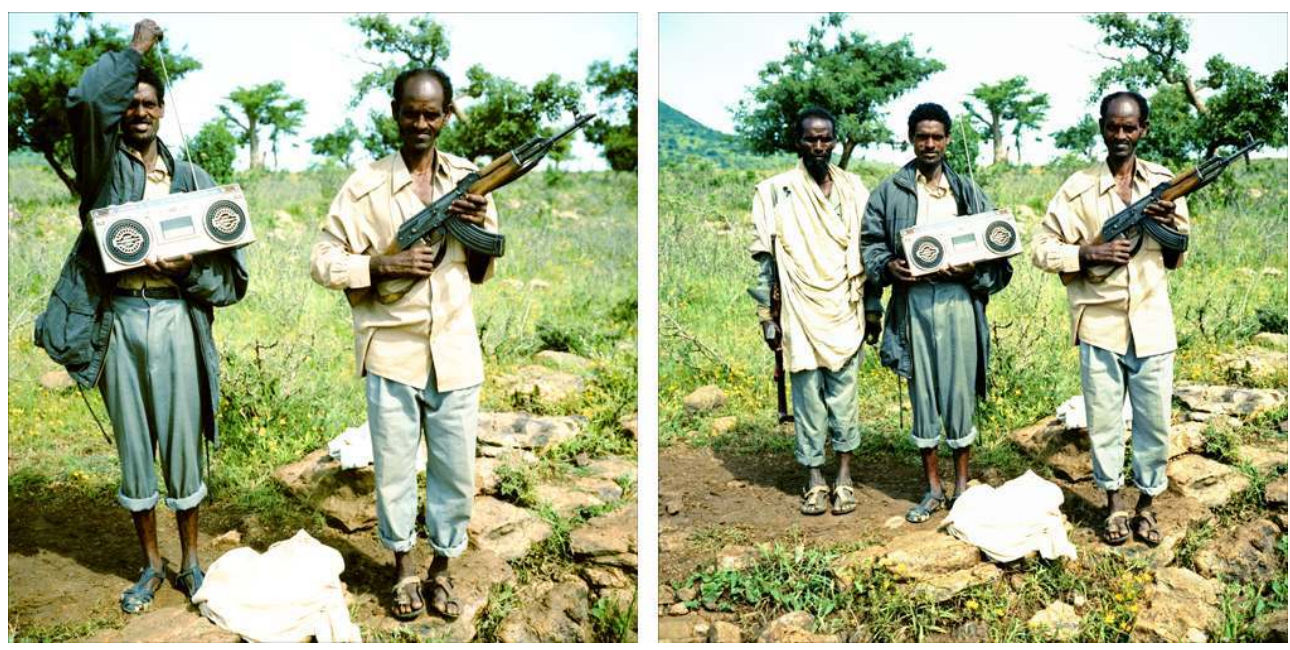

Photo by Thera Mjaaland/BONO

\section{The Beginning: Learning the Local Portrait Convention}

In 1993, before I had started to study social anthropology, I set out as an art photographer to capture everyday life in the aftermath of the liberation struggle in Tigray, NorthEthiopia. This was at a time when international journalists had long left for new wars elsewhere. I had chosen Tigray because of the significant role that women had played in the armed liberation struggle which had started in 1975 and ended with the overthrow of the country's military regime in 1991. However, as much as I had imagined these documentary photographs in advance, the people I met had their own ideas about how to be represented that shaped both the photographic encounter and the images produced. In fact, the documentary genre's strategy of non-intervention failed since people would pose as soon as they spotted my camera [Fig 1]. Despite my frustration, I accepted photographing these frontally posed photographs with hands along the sides informed by bodily and emotional containment while waiting for other decisive moments in my documentary pursuit. Walking around with my camera visible I was, however, often asked to photograph the people I met. In these ad hoc situations the surrounding landscape inevitably constituted the "studio-backdrop". If photographed when I was visiting their home, people would sometimes provide a tarpaulin, a blanket or shawl as backdrop. In fact, in what I have termed the "photographic situation" (Mjaaland 2004: 51), more people than those who appear in the photographs were commonly present, involved in holding the backdrop and/or instructing people how to behave in front of the camera [Fig. 2]. I have also as much as possible brought back enlarged copies $(20 \mathrm{x} 20 \mathrm{~cm})$ of the people I have photographed or their families on later visits since I continue to use my analogue medium-format camera with film that cannot be processed in Tigray (or Ethiopia). In fact, my outdated equipment has increasingly been subject to "bullying" by local photographers who promptly embraced digital photography. When people criticised me for representing them as too dark-skinned, I started using flash to compensate for the stark contrasts created by the bright sunlight. 
Fig. 2. Photographic situation. Adi Erar, Tigray 2001
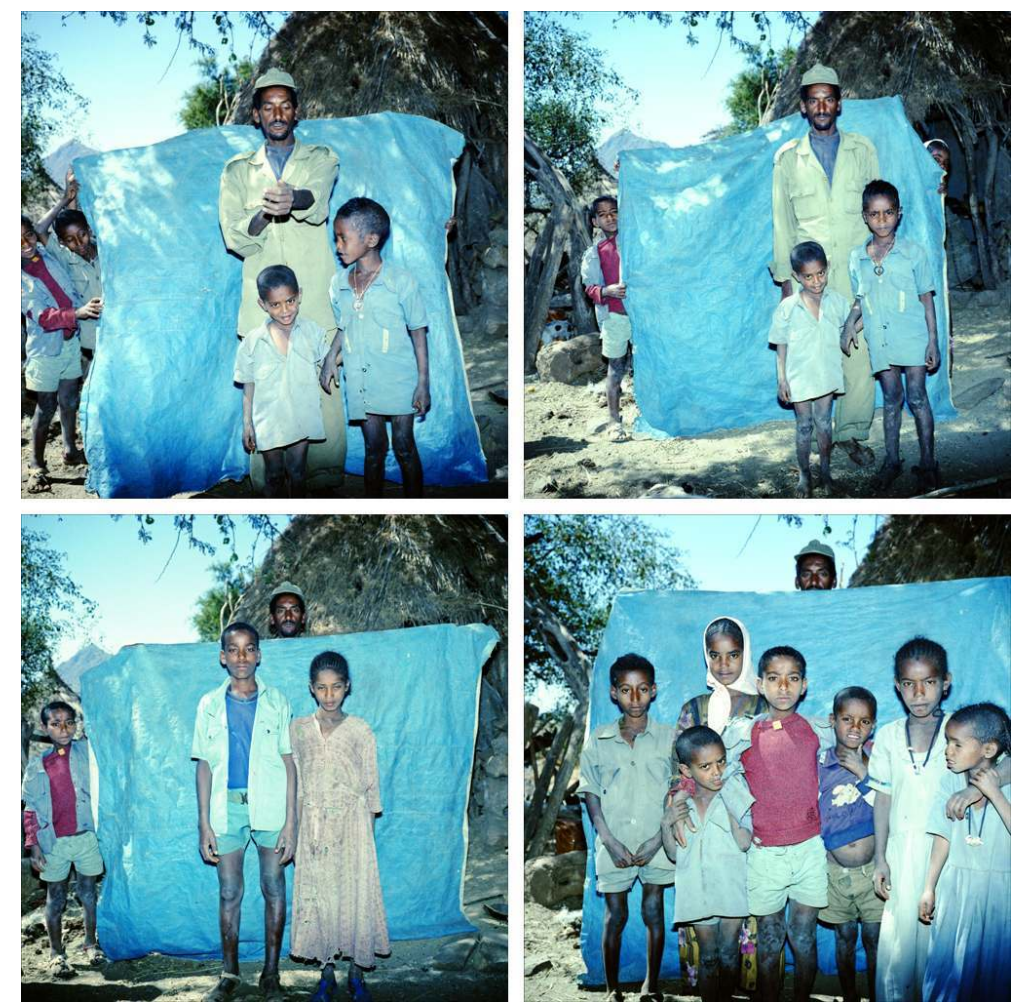

Photo by Thera Mjaaland/BONO

3 As my collection of posed photographs grew, the number of comparable images became so pressing that I was "forced" to consider them in their own right. The reason why I thought at first that these images were uninteresting was not only because I had wanted to take documentary photographs. It was because these poses referenced a Western studio portrait convention from the time when photography was introduced during the first half of the nineteenth century - and informed the dispersion of the medium to other continents including Africa - that had made me dismiss them as inauthentic. What upset this interpretation was first and foremost peoples' comments on my cropping of these photographs. I had from the start been conscious of the power relations that can be reaffirmed in visual representations through the constitution of a particular point of view - and consequently the spectator's gaze. On a vertical axis, the point of view relates to the degree of symbolic power (or lack thereof) involved in the relationship, while on a horizontal axis it relates to the closeness or remoteness of the relationship (see also Lutz \& Collins 1993; Jewitt and Oyama 2003). In the portrait-series eventually titled Ethiopian Encounters, the viewer is confronted with the direct gaze of the photographed person who is placed at the same eye-level and near enough to signify an encounter [Fig. 3]. But despite the best of my intentions, the half-figure

4 I had resorted to instead of the full-figure pose from a distance was not in accordance with common sentiments about what was required to represent a person in the Tigrayan context, which at the time had not been influenced by more "modern" trends evolving in photo-studios in towns in Ethiopia where more elaborate half-figure and close-ups indeed are in the repertoire. 
Fig. 3. Goytom, Gideon and Abrahaley. Mayshek, Tigray 2001
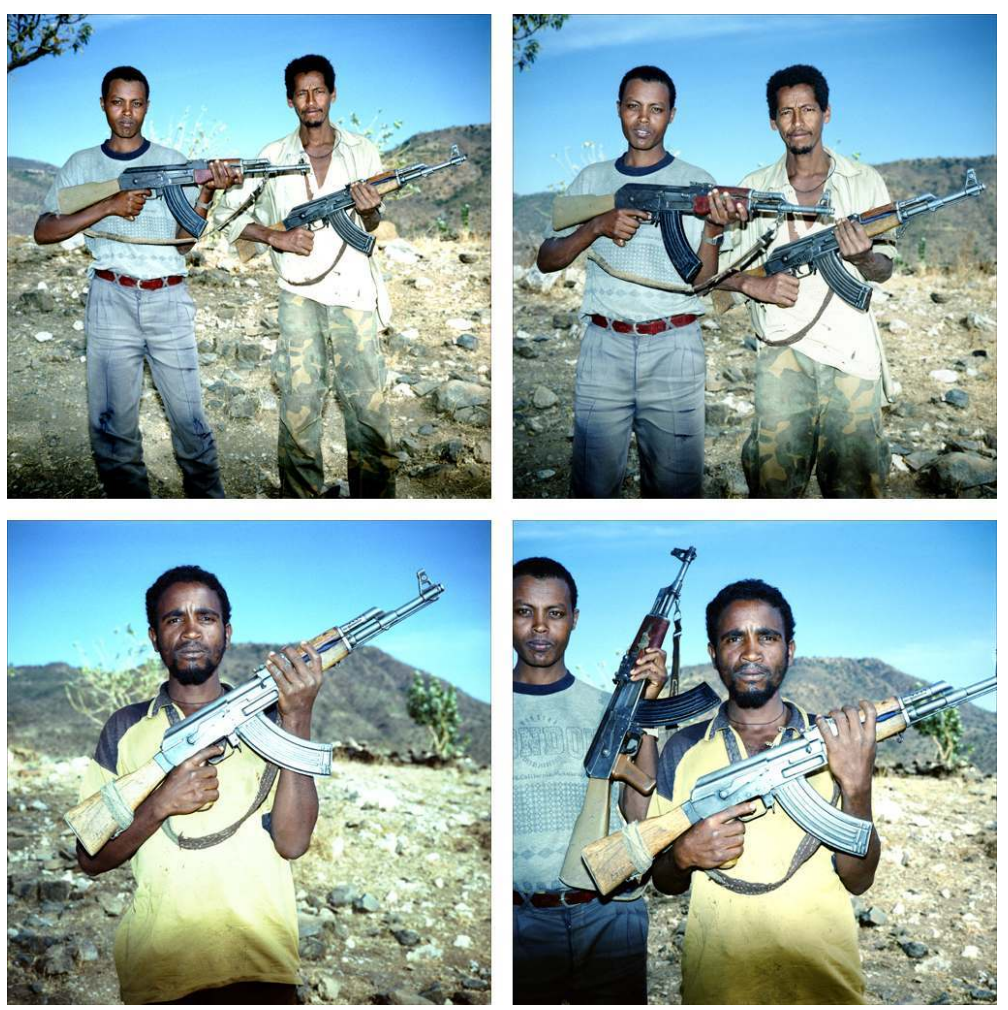

Photo by Thera Mjaaland/BONO

Their rationale was, I learnt, that to represent a person the whole body must be included. My rationale was based on (1) a Western portrait tradition where the person's face is seen as the entrance to an authentic self or soul and, therefore, representing the whole person metonymically; and (2) my wish to establish a sense of closeness to and identification with these people as a corrective to Western audiences who seemed to have accepted as a timeless fact that Ethiopians are victims of famine only. The local rationale was, however, in line with Karl Heider's writings on anthropological film based on the objectivist ethnographic principles of non-intervention and a "holism" that requires the inclusion of "whole bodies", "whole people", "whole interaction" and "whole acts" (Heider 2006 [1976]: 5). According to these principles the filmed persons are not supposed to look into the camera-lens since it would disrupt the objectivist gaze that positivism requires. However, the positioning of the photographer - and the intervention on which the ethnographic encounter is always based - is implicitly visible in both photographs and films as a partial perspective from a specific point of view. Photographic representation therefore poses a challenge to what Donna Haraway has termed "the [positivist] god trick of seeing everything from nowhere" (1988: 581), but that in her opinion, produces irresponsible knowledge claims. In the following examples I will therefore discuss what a more interventionist-based collaborative process of photographing made me "see" that I would not otherwise have noticed because I would not have thought of posing my questions in that particular direction. For example, I would not have been attentive to what threatens the autonomy of the person in this context if it had not been for the photographic imperative on bodily and emotionally contained wholeness. 


\section{Managing Exposure and Containment}

6 According to Richard Pankhurst and Denis Gérard (1999), it was first and foremost the royalty and nobility's embrace of portrait photographs in their quest for or reaffirmation of power that had prepared the path for photography's popular reception in Ethiopia. Donald N. Levine (1967) also indicates a fundamental change of attitude towards photography in the country in the 1950s and 60s. Whereas previously people in rural areas had objected to being photographed because of the camera's association with the evil eye, visitors with cameras suddenly started to be "deluged with requests for photographs. In the interim the peasants had been exposed to numerous photographs of the Emperor and high government officials and had observed their local authorities seizing every chance they could to be photographed" (88). While delinked from the camera-lens, the belief in the evil eye as well as other -uncontrollable forces that may take hold of a person nevertheless prevails in my study area in Tigray.

7 It is the buda, an ambiguous human being with the ability to transform himor herself into a hyena at night, who can cast the evil eye on somebody and "eat" that person from within. Jealousy and envy are the emic explanations for why buda casts the evil eye on somebody. What is relevant for my discussion is that this affects how people present themselves in daily life, since it is important for people to not stand out more than others in a personal, social and/or material sense. In line with the impact on behaviour of Jeremy Bentham's Panopticon of 1791 (in Batchen 1999), knowing that an unpredictable power can see you, but not knowing when, means that the person has to control him or herself continuously. This self-control also extends to the showing of strong emotions like jealousy as well as prolonged grievance as a result of bereavement or loss (beyond the social rituals that take care of it). In fact, lack of self-control risks "cracking up" the body for other malign forces to enter, like Shetan (the Devil) or Devil-like entities like jinni or aganinti, and even zar possession. If a person gives in to their emotions and loses selfcontrol, these forces can take advantage of the consequent "cracks" in bodily containment and take hold of that person. Even cracking up in a smile when photographed was not commendable (even though they might struggle not to) (Fig. 4). 


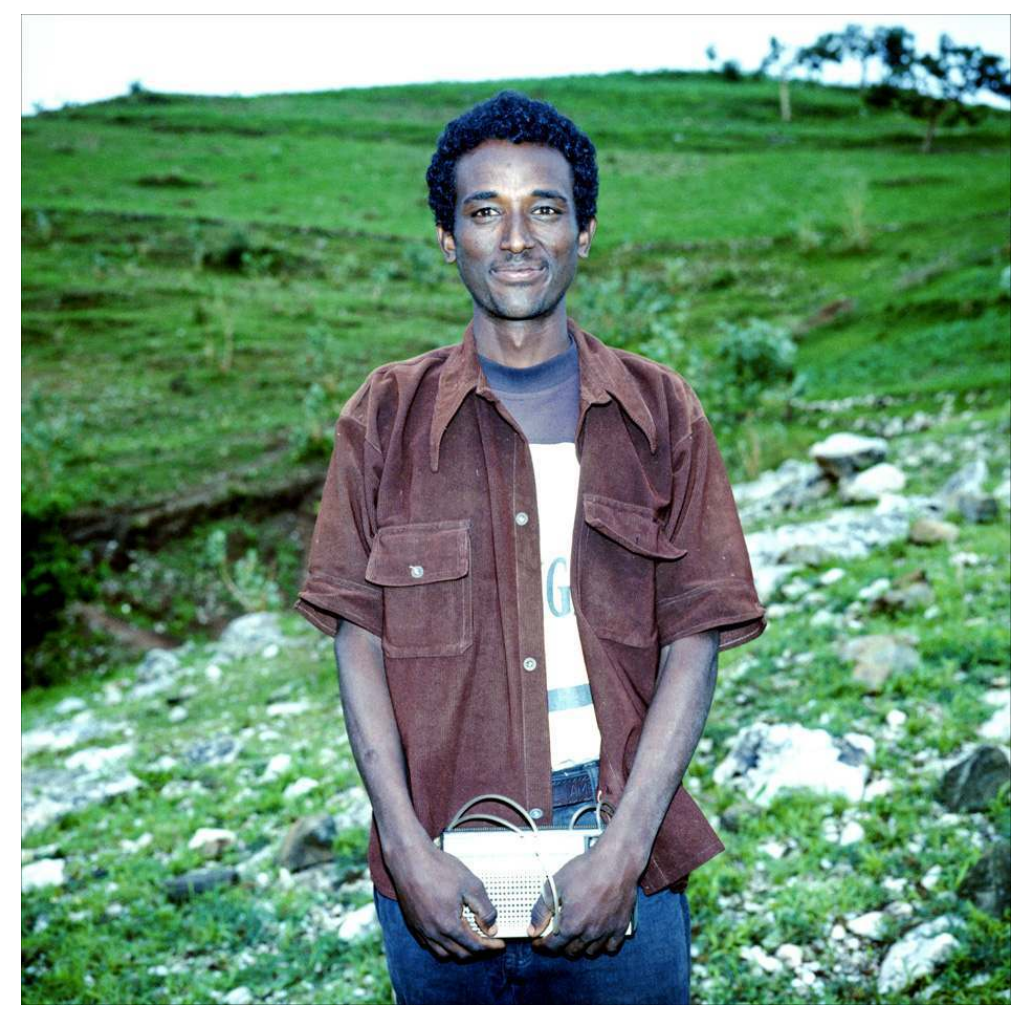

Photo by Thera Mjaaland/BONO

There are also other reasons for shutting up and keeping quiet spanning in scope from gossip to political prosecution. This was the focus of my MA thesis, I Keep Quiet: Women's Agency in Western Tigray, Ethiopia (Mjaaland 2004) that explored how silence and the skilful layering of communication allowed women a space for agency within the social norms informing their gender. Many authors on Ethiopia have pointed to this layering of communication at the base of the popular poetry tradition qïné which originated and is still b taught within the Ethiopian Orthodox Church (e.g. Levine 1967; Maimire 2005-6). In the wax-and-gold trope of the qïné dynamic, "wax" signifies surface meaning while the "gold" signifies a deeper hidden insight. In fact, Maimire Mennasemay (2010) understands the subversive and subjugated dimension of the qïné dynamic, the "gold", to harbour a critical potential that is "active silently" (76). Levine (1967) defines three mundane situations where the qïné dynamic is at play in social life. These are when someone wants to (1) insult somebody but at the same time seeking to avoid social sanctions; (2) defend one's privacy against social intrusion like rumours and gossip; and (3) challenge authorities in a way that reduce the risk of punishment (9). In line with Levine's definition, in the local context of north-western Tigray I found that disclosing biographic information and personal opinions without consideration as to whom it is told, exposing what is considered too much about one's immediate or future plans, or voicing potentially controversial opinions openly, are considered irresponsible, or outright foolish. When posing frontally with hands along the sides and contained expressions (seen as village-like, or "backward", from the point of view of people living in urban areas), rather than just mimicking an outdated Western studio convention, this bodily posture pointed to the need for containment, rather than disclosure in social life. 
In fact, the process of co-photographing suggested bodily and emotional containment as a discursive social practice that defines the person in this context. While being seen continues to be risky in this context, it is important to take note of the distinction between the lack of control over one's own body inherent in the discourse on the evil eye, and the potential power to define oneself through photographic self-representation, which promises a form of eternity in a visual sense.

\section{Managing Visibility and Invisibility}

9 Jaques Lacan's (1996 [1949]) understanding of the mirror stage when the child is aged 6-18 months is frequently used to understand how photographs can enter into self-defining processes. What is at issue here is the impact on personhood of this coherent image that for the first time is apprehended in the mirror (albeit at first misrecognised as another person). Marianne Hirsch asserts that the "mirrored" self as we know it from personal photographs can produce an "ideal self" that "disguises the profound incongruities and disjunctions on which identity is necessary based" (Hirsch (1997: 101). The reason for this is, as Jean-Francois Werner (2001) has noted, is "the remarkable plasticity of this [...] technology of representation" (264) that, while giving the impression of being true, can be fiction. What Elisabeth Edwards calls the "ambiguities of the realist paradigm" (55) is disguised precisely by the medium's realism. In fact, the photographic medium's ambiguity (see also Mjaaland 2012b) can gain particular significance in a context informed by the wax-and-gold trope of the qïné dynamic, and which produces according to Levine (1967) a "cult of ambiguity" (10). Based on the resulting "secretogenic" social structure (Levine 1985:33), photographs can thus accommodate the need to layer communication in social interaction by upholding the "wax" in order to contain the "gold". 
Fig. 5. Mihirey Belete, Abate Gebretsadek and Mihirey Girmay. Alogen, Tigray 1997
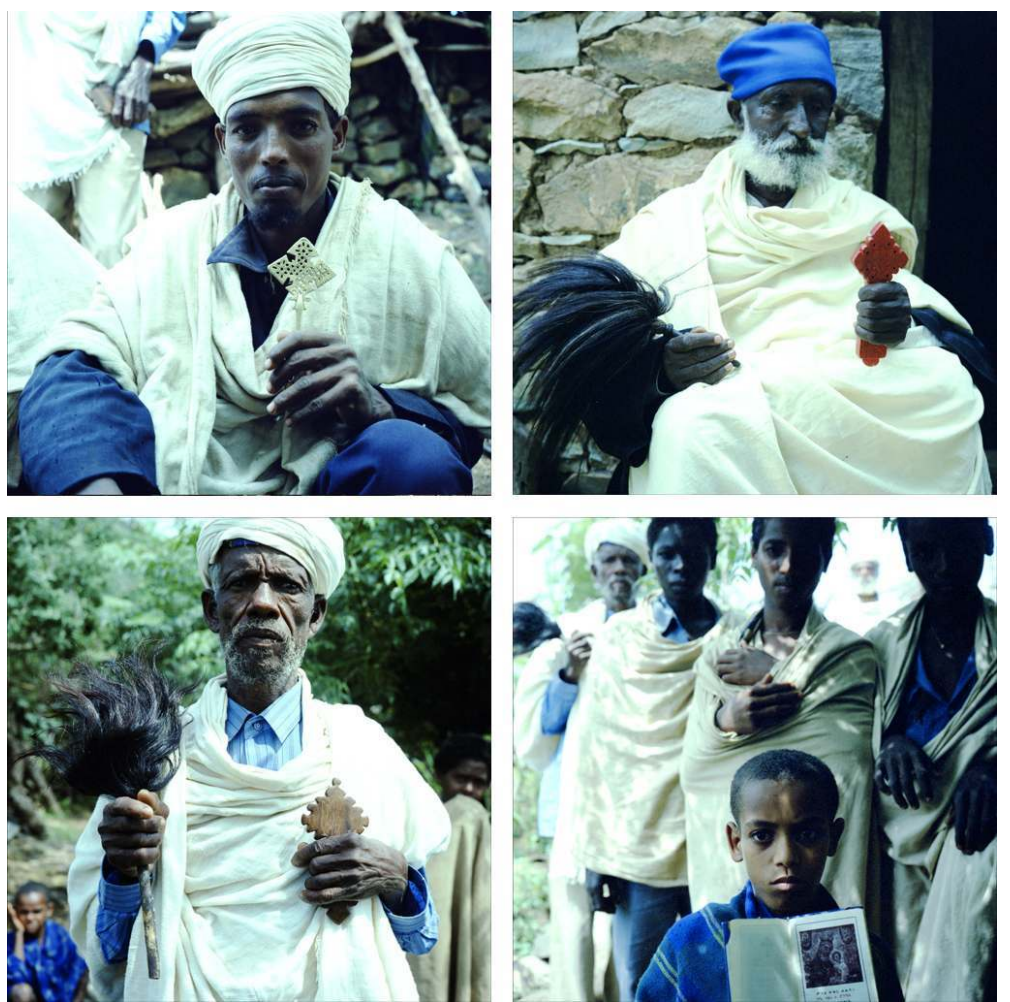

Photo by Thera Mjaaland/BONO

To be photographed holding different objects is well established as a photographic convention in my study area in north-western Tigray (Fig. 5). These material attributes that include everything from green leaves, flowers and cultural or religious artefacts to weapons and a radio can be understood as objects of identification. From the start these photographs also had a clear male bias, as reflected in the photographs above, and with no former fighter women posing with guns. However, rural female students holding their schoolbooks had started to emerge in my photographic material from this area of Tigray in 2002 and onwards (see Mjaaland 2004; 2013a). These girls who knew me from their village invited me to come to their rented quarters in town where they had moved in order to continue their education from Grade 5 (later from Grade 8) onwards; a move that commonly implied having resisted their parents' wish to marry them off while still underage. Interestingly, it was female rather than male students who asked me to photograph them with their schoolbooks. In these poses the girls clearly constitute themselves as students. But these images also allow for an imaginative projection towards the future that reinforces an interest or commitment to become educated. This perspective draws on Mustafa Emirbayer and Ann Mische's (1998) cordial triad of agency which contains "iteration" (repetitiveness), "projection", and "practical evaluation" of both in the present. These authors explain projection as "the imaginative generation by actors of possible future trajectories of action, in which received structures of thought and action may be creatively reconfigured in relation to actors' hopes, fears and desires for the future" (971). Hence, rural female students' self-representations with schoolbooks, as a practical evaluation in the photographic situation, would encompass a 
reconfiguration of the iterative social context that they have to negotiate in order to reach their imagined future as educated women.

Fig. 6. Abrehet. Endabaguna, Tigray 2002
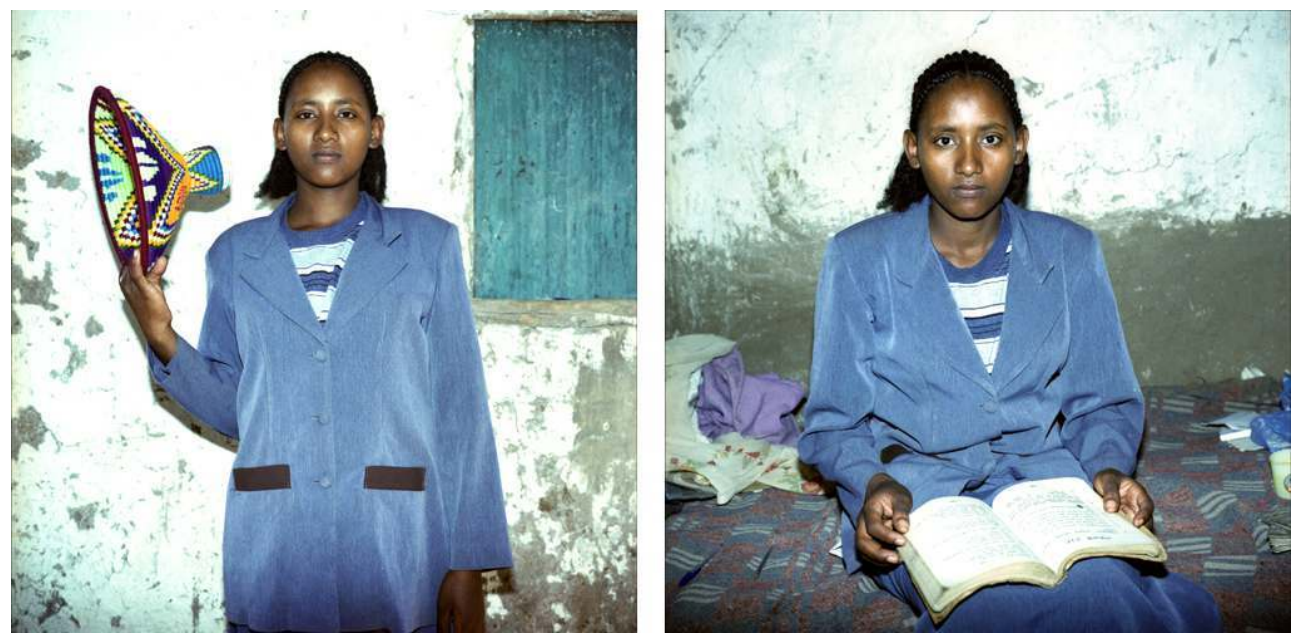

Photo by Thera Mjaaland/BONO

Fig. 7. Akberet. Endabaguna, Tigray 2002
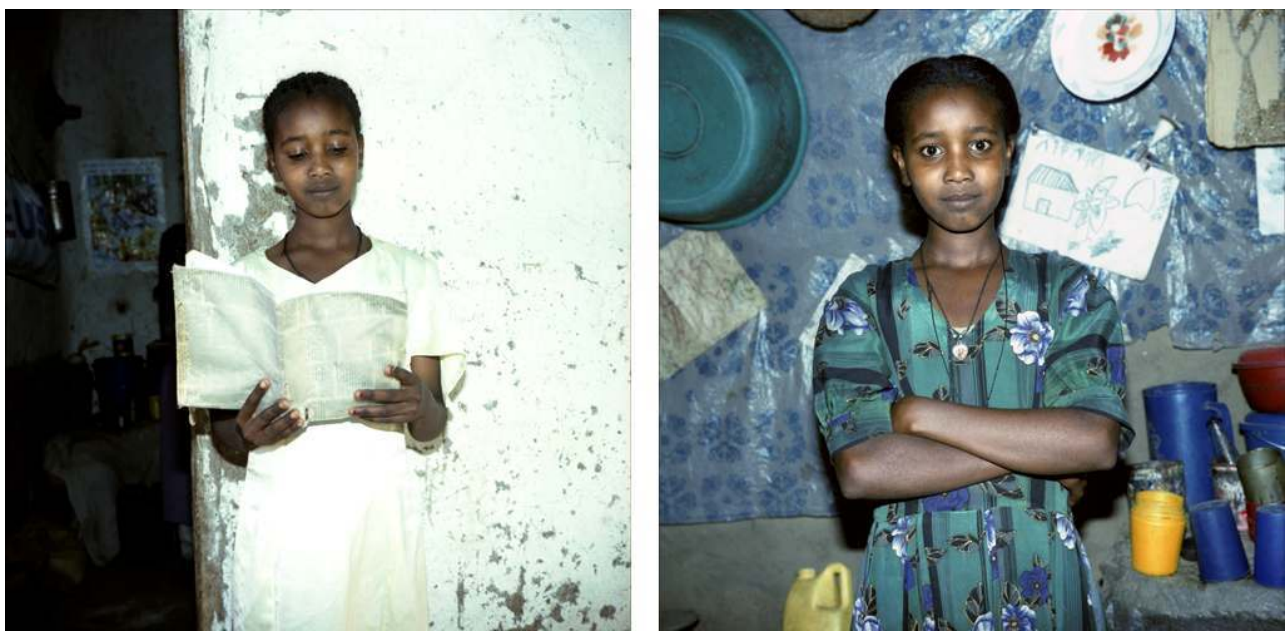

Photo by Thera Mjaaland/BONO

For example, the moral implications of moving outside their parents' control in order to continue to secondary school in town, hit these rural girls harder than their urban female age-mates who can continue to stay at home, and harder than both rural and urban boys whose sexual morals are not questioned. Girls' parents are generally seriously concerned about their daughters' morality, as girls are believed to start being sexually active from around the age of fifteen,whether married or not. School is one arena where girls get to know boys and might start dating in secrecy. In a girl's parents' perceptions at worst, she might end up losing her virginity, fall pregnant and eventually drop out of school; damaging both her and her family's reputation in the community. The reason why I propose these self-representations as practical evaluations in the present is based on the fact that these girls shifted their self-representation between schoolbooks and cultural attires and artefacts like the mokombïa which is used as a head-decoration for the bride 
at her wedding (Fig 6). While many of these girls wanted to pose in modern ready-made clothes when photographing them in their rented quarters in town, I also observed how they would be careful to change their appearance to more village-like dresses, with tight bodies and long skirts,when leaving for home in the rural area (Fig. 7). It is from this perspective that I understood being photographed with schoolbooks is part of these girls' practical evaluation in the present between the gendered obligations of an agrarian society and the new possibilities opened up for them through continuing education in urban contexts. In fact, the photographic situation constituted a space for selfrepresentation where identity could be acted out and tested in a visual sense - a "discursive site for struggle", to paraphrase Chandra Mohanty (1991:32). In so doing they were managing both visibility and invisibility.

Fig. 8. Kichin. Mayshek and Endabaguna, Tigray 2009
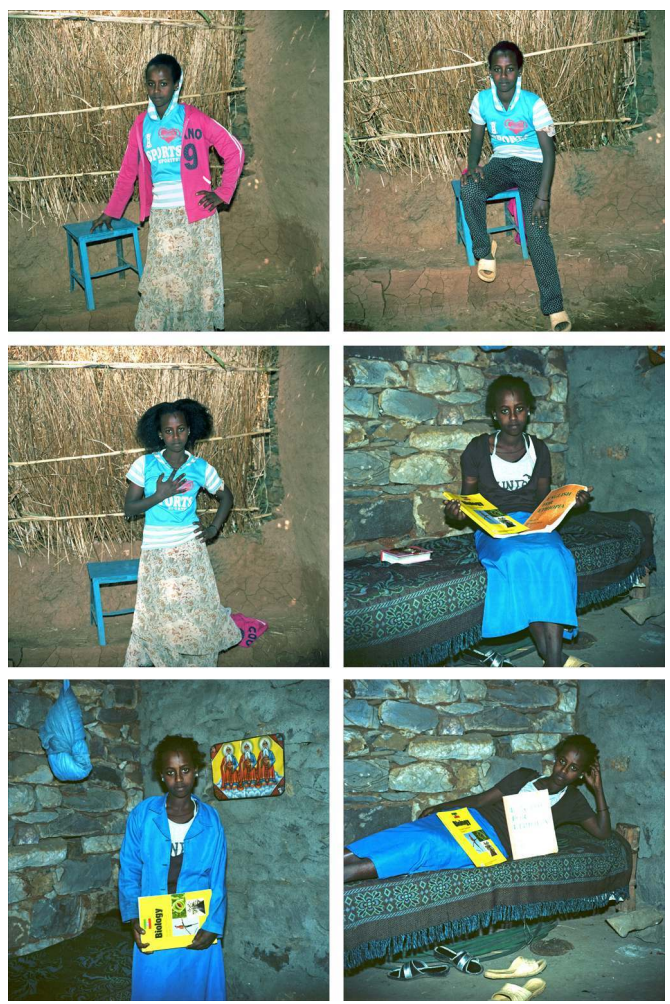

Photo by Thera Mjaaland/BONO

Debbora Battaglia's (1997) concept of "invisible foregrounding" is relevant here. She asserts that there is complex work of ambiguation taking place at the "borders" (with a reference to the Tigrayan fighter women I suggest "frontiers") conjoining the domains of the stated and the unstated. What is relevant for my discussion here is that making something invisible, in Battaglia's understanding, by way of absence and displacement, implies a move from the presupposed and taken-for-granted to a conscious taking of control. Rural female students' self-representations are not without challenge to the prevailing ideal of female modesty when posing in more "modern" urban attire like trousers or with their hair loose; drawing on influences from a larger context of global youth culture that is transmitted through fashion and television in town - and increasingly their smart-phones (Fig. 8). At the same time, their poses seem to continue to draw on the female modesty ideal. Invisible foregrounding (or making invisible), is one 
strategy that these Tigrayan girls can use when pursuing an education impinges on their ascribed sexual morality in terms of being classified as "damaged" if having lost their virginity, and risk being placed in the category "immoral" by the very fact of going to school - irrespective of having a boyfriend or not. Or when their independence, mobility and forthrightness do not fit within the ideal of modest femaleness, and result in these girls being classified as "male". This had been the case for the courageous and forthright fighter women who in the 1970s and 80s participated in the Tigrayan struggle on equal footing with men (see also Krug 2000). Relevant still is therefore Zenebework Tadesse's (1976) assertion from four decades ago that "energy and creativity are synonymous with masculinity in spite of great contributions by women. Whenever a woman appears to be particularly gifted, she is complimented by comparison with men (4; emphasis in original). With a reference to Zenebework, Bilen Gisaw states that, "[f]orthrightness in women is viewed as unfeminine" (Bilen 2002: 36). At the "frontiers" of the stated and the unstated, these Tigrayan girls can therefore be understood to be involved in complex ambiguation work in their handling of visibility and invisibility, since it is still important to be seen as respectable girls and to make invisible what is perceived by the society as female "immorality" as well as the "maleness" of their forthrightness. Hence, the way these girls evaluated practically their appearances and postures in the photographic situation might challenge but does not necessarily constitute a break with sanctioned gender norms and the modest femaleness they are socialised into. However, it was these practical evaluations in the present that the collaborative process of photographing made me see (Fig 9).

Fig. 9. Roman. Mayshek, Tigray, 2014
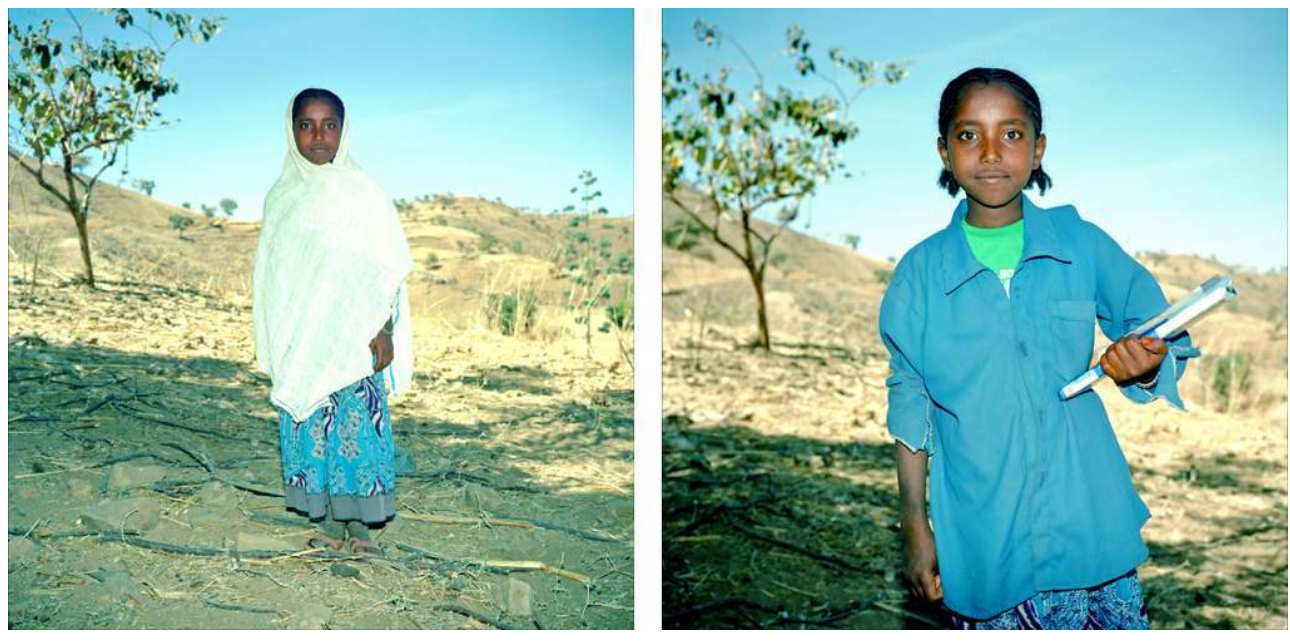

Photo by Thera Mjaaland/BONO

\section{Ethical Guidelines and the Implicit Presumption of Inequality}

Since my first visit to Ethiopia photography has played a major role in my interaction with people, not least in what came to be my study area in north-western Tigray. In the interventionist-based co-photographing that evolved, as the photographing anthropologist I was also repositioned from a detached observer using photography for 
objective description and the production of evidence to a social actor in an evocative encounter (see also Mjaaland 2009). It was this repositioning together with the openendedness of artistic exploration that enabled me to "see" the subtle mediation related to the layered socio-cultural dynamics in this context of exposure and containment, visibility and invisibility. This co-photographing also shares a basic tenet with Sarah Pink's understanding of her photographic practice during fieldwork "as a dynamic relationship between those who occupy the spaces on both sides of the viewfinder" (Pink 1999: 83). Who holds the power to define in the photographic situation is not then solely the photographer. Since the power to define also includes the selection of photographs afterwards I therefore prefer, as much as possible, to present all photographs taken of one person rather than choosing the "best" image in order to indicate the process where I was commonly allowed to photograph two or three images. The feedback on these images from the photographed persons has been decisive for my analysis, and their names are included in the captions of the photographs.

Needless to say, photographs make identification of the person possible. "Half"anonymising the photographed person by not providing their names in the captions would, in my opinion, contribute to a long colonial tradition of seeing Africans as an undifferentiated mass and not as individuals in their own right. People have consented to being photographed since they are commonly the ones who ask me to take their picture in the first place. If invited to an event like weddings or a Christening party I am expected to take photographs, and people express their disappointment if I do not bring my camera. When giving people their photographs on later visits to the area I have listened carefully to theirs and other bystanders' comments of the images. If practically possible, showing them the final photo layout before publishing has also in some cases enabled renegotiated consent. When seeing the publication afterwards disappointment has often been generated by the fact that their photograph was not included rather than the other way around. Their concern is therefore not first and foremost with the photographs going public, which might generate a sense of pride and importance. Rather it is that they assume I earn a lot of money from selling their photographs. The fact that I do not feel comfortable with selling these images continues to be, for them, simply unbelievable; as this is perceived as my reason for photographing them in the first place. However, their concern has not resulted in stopping to ask me to photograph them - often repeatedly over years (Fig. 10). 
Fig. 10. Negassie, Mayshek, Tigray 2002 and 2010
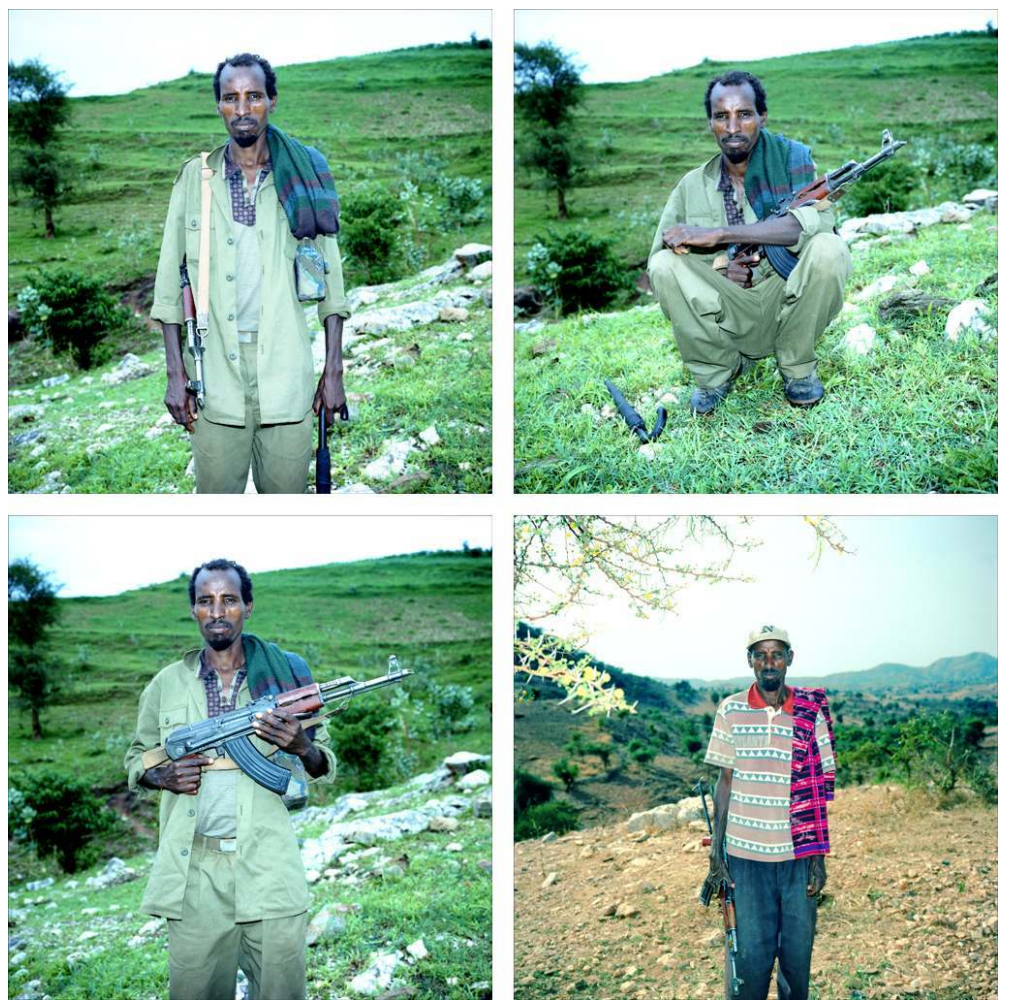

Photo by Thera Mjaaland/BONO

Furthermore, I have not asked those who wanted me to photograph them (or those I interviewed) to sign consent forms, even if the Norwegian Social Science Data Service (NSD) would prefer that I did. In a context where upholding secrecy and creating ambiguity continues to be important, signing a consent form is perceived as a breach of confidentiality and trust that increases their social and political vulnerability, since the use of the signed document is out of their control afterwards. While neither the researcher nor the researched can possibly foresee all consequences of using photographs in research, Western ethical guidelines, which require anonymization, become as much a way for the researcher to protect herself as protecting the participants (see also ScheperHughes 2000). My conscience was therefore drawn in the opposite direction when delinking photographs from textual narratives: using real names in the caption of the photographs and fake names in the text; or not using photographs of those who speak in the text at all. Despite the best of ethical intentions, the result of this anonymization is that it becomes difficult to acknowledge peoples' contributions to our research. Rather than protection, anonymization itself fare becoming a reaffirmation of an unequal power relation, which blocks the possibility for making more visible aspects of collaboration and "shared authority" (Frisch 1990; Shopes 2003) in practice.

16 My argument, I found, is in line with Kivin Strohm's (2012) perspective on the politics of collaboration. He asserts that the ethical commitment to collaboration is clearly guided by the "presumption of inequality". He asserts:

... this presumption of inequality is deeply flawed insofar as it perpetuates the very colonial vestiges that anthropology has been working to undermine since the 1960s, and moreover, it reproduces the vertical relationship of anthropology with its other. To put it 
simply, I argue that we should consider presuming, or better, presupposing equality (Strohm 2012: 102).

Strohm criticises the very notion that equality is something that can be given or provided by the anthropologist. Instead, he argues that the anthropologist has to respond to people's assertion or affirmation of equality in the ethnographic encounter as a political act which disrupts the spatial and temporal ordering of bodies. His presupposition of equality then goes beyond merely addressing, as an ethical issue, the power of representation. In my earlier writings (Mjaaland 2013a), I have suggested that the photographic situation can usefully be understood in terms of what Homi Bhabha (2006 [1994]) conceptualises as "the third space" (see also Bhabha and Rutherford 1990), where the hybridity emerging from translation across incommensurable differences gives rise to something new and different depending on a collaborative process of listening, understanding and learning. Strohm (2012) asserts, in a similar vein, that equality exists when our encounter with the people we work confronts the anthropological episteme; when our preconceptions are disrupted and suspended and reconfigurations are allowed to take place. The ethnographic examples presented in this article shows how this have played out through a co-photographing in north-western Tigray that also disrupts prevailing positivist norms for visual representation in anthropology.

\section{Concluding Note}

The co-photographing that developed in the encounter with Tigrayan people who insisted on taking control over their own self-representation,together with their critique of the photographs afterwards has, therefore, enabled a certain degree of shared authority, or "shared anthropology" in the French filmmaker Jean Rouch's conception (Rouch 2003:101), and more so than in interview situations where I was expected to take the lead to make sure that they did not disclose more information than what was strictly necessary in order to answer my questions. Discussing my photographic portraits from the series, Ethiopian Encounters, in his article, Art/Anthropology Interventions, Arnd Scheider (2016) writes that "ethical relationships, however tenuous and temporary, can be constructed in such artistic interventions [that Mjaaland explores]" (208). To be able to do so it does make a difference if the artist photographer/photographing anthropologist approaches these evocative encounters in the photographic situation with the presumption of inequality or presupposes equality.

\section{BIBLIOGRAPHY}

Ethiopian authors are listed by their first name

Aspen, Harald. 1994. Spirits, Mediums, and Human Worlds: the Amhara Peasants of the North Ethiopian Highlands and Their Traditions of Knowledge. Doctoral thesis in anthropology. Trondheim: Norwegian University of Science and Technology. 
Battaglia, Debbora. 1997. Displacing the Visual: Of Trobriand Axe-blades and Ambiguity in Cultural Practice. In Rethinking Visual Anthropology. Banks, M. and H. Morphy, eds. Pp. 203-215. New Haven, London: Yale University Press.

Bhabha, Homi. 2006 [1994]. The Location of Culture. London, New York: Routledge.

Bhabha, Homi and Jonathan Rutherford. 1990. The Third Space. Interview with Homi Bhabha. In Community, Culture, Difference. Rutherford, J. ed. Pp. 207-221. London: Lawrence and Wishart.

Boddy, Janice 1989. Wombs and Alien Spirits. Women, Men, and the Zar Cult in Northern Sudan. Wisconsin, London: The University of Wisconsin Press.

Edwards, Elisabeth. 1997. Beyond the Boundary: a Consideration of the Expressive in Photography and Anthropology. In Rethinking Visual Anthropology. Banks, M. and H. Morphy, eds. Pp. 53-80. New Haven, London: Yale University Press.

Emirbayer, Mustafa and Ann Mische. 1998. What is Agency? The American Journal of Sociology, 103 (4):962-1023.

Frisch, Michael. 1990. A Shared Authority: Essays on the Craft and Meaning of Oral and Public History. Albany: State University of New York Press.

Haraway, Donna. 1988. Situated Knowledges: The Science Question in Feminism and the Privilege of Partial Perspective. Feminist Studies, 14(3): 575-599.

Heider, Karl G. 2006 [1976]. Ethnographic Film. Austin: University of Texas Press.

Jewitt, Carey and Rumiko Oyama. 2003. Visual Meaning: a Social Semiotic Approach. In Handbook of Visual Analysis. Leeuwen, T.V. and C. Jewitt, eds. Pp. 134-156. London: Sage Publications.

Kothari, Uma and Bill Cooke. 2001. Participation: the New Tyranny? London: Zed Books.

Krug, Stephanie. 2000. Anthropologie der Kriegs- und Nachkriegszeit in Äthiopien. Münster, Hamburg, London: Lit Verlag.

Lacan, Jacques. 1996. Spegelstadiet som utformare av jagets funktion sådan den visar sig för oss i den psykologiske erfarenheten (1949). In Écrits. Spegelstadiet och andra skrifter i urval. Matthis, I., ed. Pp. 27-36. Stockholm: Natur och Kultur.

Lassiter, Luke Eric. 2004. The Chicago Guide to Collaborative Ethnography. Chicago and London: University of Chicago Press.

Lassiter, Luke Eric 2005. Collaborative Ethnography and Public Anthropology. Current Anthropology, 46(1):83-106.

Levine, Donald N. 1967. Wax and Gold. Tradition and Innovation in Ethiopian Culture. Chicago, London: The University of Chicago Press.

Levine, Donald N. 1985. The Flight from Ambiguity. Essays in Social and Cultural Theory. Chicago, London: The University of Chicago Press.

Lewis, Ioan M. 1996. Religion in Context. Cults and Charisma. Cambridge: Cambridge University Press.

Lutz, Caterine and Jane Collins. 1993. Reading National Geographic. Chicago and London: The University of Chicago Press.

Maimire Mennasemay. 2005-06. Ethiopian Political Theory, Democracy, and Surplus History. International Journal of Ethiopian Studies, 2(1/2):1-32. 
Maimire Mennasemay. 2010. Towards a Critical Ethiopian Theory of Education. In, Education, Politics and Social Change in Ethiopia. Paulos Milkias and Messay Kebede, eds. Pp. 67-97. Los Angeles: Tsehai.

Mjaaland, Thera. 2004. Ane suqh' ile. I Keep Quiet. Focusing on Women's Agency in Western Tigray, North-Ethiopia. Cand. Polit./MA-thesis in Social Anthropology. Bergen: University of Bergen.

Mjaaland, Thera. 2006. Saleni, fotografer meg! Om sammenhenger mellom fotografisk representasjon og forståelse av personen i Tigray, Etiopia. Norsk Antropologisk Tidsskrift. 17 (1):33-47. Oslo: Universitetsforlaget.

Mjaaland, Thera. 2009. Evocative Encounters: An Exploration of Artistic Practice as a Visual Research Method. Visual Anthropology, 22(5):393-411.

Mjaaland, Thera. 2013a. At the Frontiers of Change? Women and Girls' Pursuit of Education in North-western Tigray, Ethiopia. PhD-thesis in Gender and Development. Bergen: University of Bergen.

Mjaaland, Thera. 2013b. Traversing Art Practice and Anthropology; Notes on Ambiguity and Epistemological Uncertainty. In Anthropology and Art Practice. Schneider, A. and C. Wright, eds. Pp. 50-59. Oxford; New York: Berg.

Mohanty, Chandra T. 1991. Under Western Eyes. Feminist Scholarship and Colonial Discourses. In Third World Women and the Politics of Feminism. Mohanty, Chandra T, A. Rosso and L. Torres, eds. Pp. 51-80. Bloomington: Indiana University Press.

Pankhurst, Richard and Denis Gérard. 1999. Court Photographers. In Anthology of African \& Indian Ocean Photography. Leon, P.M.S, N. Fall and J.L. Pivin, eds. Pp. 118-133. Paris: Review Noire.

Pink, Sarah. 1999. A Woman, a Camera and the World of Bullfighting: Visual Culture as the Production of Anthropological Knowledge. Visual Anthropology, 13(1):71-86.

Rouch, Jean. 2003. On the Vicissitudes of the Self: The Possessed Dancer, the Magician, the Sorcerer, the Filmmaker, and the Ethnographer. In Ciné-Ethnography. Jean Rouch. Feld, S., ed. Pp. 87-101. Minneapolis, London: University of Minnesota Press.

Scheper-Hughes, Nancy 2000. Ire in Ireland. Ethnography, 1(1):117-140.

Schneider, Arnd. 2016. Art/Anthropology Interventions. In Practicable: From Participation to Interaction in Contemporary Art. Bianchini, S. and E. Verhagen, eds. Pp. 195-213. Cambridge MA, London: Mitt Press.

Shopes, Linda. 2003. Sharing Authority. The Oral History Review, 30(1):103-110.

Strohm, Kiven. 2012. When Anthropology Meets Contemporary Art: Notes for a Politics of Collaboration. Collaborative Anthropologies, 5(1): 98-124.

Werner, Jean-Francois. 2001. Photography and Individualization in Contemporary Africa: An Ivoirian Case-Study. Visual Anthropology, 14(3):251-268.

\section{ABSTRACTS}

The argument in this article, which starts from the assertion that anthropological research is always dependent on cross-cultural collaboration - whether acknowledged or not - is based on my experience from north-western Tigray, North-Ethiopia as a photographic artist and photographing anthropologist. The photographic portraits that resulted from Tigrayan people 
taking control over their own self-representation in a process of "co-photographing" made me "see" the subtle socio-cultural dynamics of layering communication mediated through exposure and containment, visibility and invisibility. My interpretation of their self-assertive strategy in the photographic situation resonates with Kiven Strohm's (2012) emphasis on responding to the research participants' assertion or affirmation of equality in cross-cultural collaborative research relationships as opposed to presuming inequality. However, Western ethical guidelines that require the anonymization of participants, and which makes it difficult to acknowledge people's contributions to our research, reaffirm, rather than challenge this presumed inequality between the researcher and the researched.

Resume

Resumen

\section{INDEX}

Mots-clés: Motscles

Keywords: co-photographing, (in)equality, Western ethical guidelines, Ethiopia

Palabras claves: Palabrasclaves

\section{AUTHOR}

\section{THERA MJAALAND}

Affiliated researcher UiB Global, University of Bergen (Norway) and Centre for Gender Studies, Addis Ababa University (Ethiopia)

Photographer and social anthropologist. Started her career as an art photographer with a Diploma in photography from Bournemouth and Poole College of Art and Design, UK (1977-80). Was exhibiting her work frequently in Norway and abroad up until the mid-1990s, before she was asked to teach photography at Bergen Academy of Art and Design, Norway (1996-99). Later appointed Dean at its Department of Specialized Arts for two years (1999-2000). She has a Cand. Polit. (MA) degree in Social Anthropology (2004), and a PhD in Gender and Development (2013) from the University of Bergen where she is currently affiliated as an independent researcher. Including still photography as method in her research, she is particularly concerned with epistemological issues linked to expanding the scope of the visual in anthropology, as well as finding new ways of photographing in accountable and responsible ways related to the postcolonial critique of the relations of power involved in photographic representation. theremjaaland@yahoo.com 